\title{
PELAKSANAAN PERJANJIAN KONSINYASI \\ DITINJAU DARI PASAL 1338 KUHPERDATA
}

\author{
Oleh : \\ Windi Arista, SH., MH \\ (Dosen Tetap Sekolah Tinggi Ilmu Hukum Sumpah Pemuda Palembang)
}

\begin{abstract}
ABSTRAK
Konsinyasi merupakan salah satu bentuk strategi produsen dalam pendistribusian produknya kepada konsumen. Secara garis besar, pendistribusian dapat diartikan sebagai kegiatan pemasaran yang berusaha memperlancar dan mempermudah penyampaian barang dan jasa dari produsen kepada konsumen, sehingga penggunaannya sesuai dengan yang diperlukan (jenis, jumlah, harga, tempat dan saat diperlukan).

Mekanisme dalam pelaksanaan konsinyasi yaitu produsen yang dalam hal ini diwakili oleh Supplier menitipkan produknya kepada pihak lain (Pasar Swalayan) untuk dijual kembali kepada konsumen dengan diikat dalam suatu perjanjian.( Dwina, Op.cit ) Dalam proses ini Supplier dan pihak yang menjualkan produk (Pasar Swalayan) merupakan perantara produsen ke konsumen dalam aliran barang.

Konsinyasi selain memberikan keuntungan bagi kedua belah pihak, dimana bagi Supplier penitipan barang dapat dijadikan sarana mempromosikan produk-produknya, terutama untuk produk-produk baru, sedangkan bagi Pasar Swalayan cara seperti ini mengurangi risiko kerugian karena apabila barang yang dititipkan itu tidak habis terjual, maka dapat dikembalikan kepada Supplier.
\end{abstract}

Kata kunci : pelaksanaan, perjanjian, konsinyasi

\begin{abstract}
Consignment is one form of producer strategy in the distribution of its products to consumers. Broadly speaking, distribution can be interpreted as marketing activities that seek to facilitate and facilitate the delivery of goods and services from producers to consumers, so that their use is as needed (type, quantity, price, place and when needed).

The mechanism in the implementation of consignment, namely producers, in this case represented by the Supplier, entrusts their products to other parties (Supermarkets) for resale to consumers by binding in an agreement. In this process the Supplier and the party selling the product (Supermarkets) is a producer to consumer intermediary in the flow of goods.

Consignment in addition to providing benefits for both parties, where for custodian suppliers of goods can be used as a means of promoting its products, especially for new products, while for supermarkets this way reduces the risk of loss because if the items deposited are not sold out, then can be returned to the Supplier.
\end{abstract}

Keywords: implementation, agreement, consignment 


\section{A. Latar Belakang}

Perjanjian konsinyasi merupakan bentuk perjanjian dimana pihak distributor menitipkan barang dagangannya kepada pihak agen atau pemasar. Perjanjian konsinyasi adalah perjanjian jual beli yang cara pembayarannya kemudian, jika yang diperjualbelikan telah laku terjual.

Perjanjian Konsinyasi sebagai salah satu bentuk perjanjian tidak bernama, menurut Sri Soedewi Masjchoen Sofwan, yang dimaksud dengan perjanjian tidak bernama adalah perjanjian-perjanjian yang dikenal di dalam masyarakat namun perjanjian tersebut tidak mempunyai suatu nama khusus di dalam KUHPer.

Senada dengan pengertian tersebut, menurut Salim HS perjanjian tidak bernama (Innominaat) adalah "Keseluruhan kaidah hukum yang mengkaji berbagai kontrak yang timbul, tumbuh dan hidup dalam masyarakat dan kontrak ini belum dikenal pada saat KUHPer diundangkan". ${ }^{67}$

Sebagai perjanjian tidak bernama konsinyasi mempunyai kesamanaan nama dengan konsinyasi yang diatur di dalam KUHPer yaitu pada Pasal 1404, namun mempunyai makna yang berbeda. Dalam KUHPer, dijelaskan bahwa konsinyasi merupakan suatu penitipan yang dilakukan di kantor panitera Pengadilan Negeri dalam hal tata cara pembayaran yang dilakukan oleh debitur, dikarenakan kreditur tidak mau menerima pembayaran debitur. ${ }^{68}$

Penolakan kreditur menerima pembayaran debitur tersebut adakalanya bermotif mencari keuntungan yang lebih besar. Adapun isi pasal 1404 KUHPer yaitu:

Jika si berpiutang menolak pembayaran, maka si berutang dapat melakukan penawaran pembayaran tunai apa yang diutangnya, dan, jika si berpiutang menolaknya, menitipkan uang atau barangnya kepada Pengadilan. Penawaran yang sedemikian, diikuti dengan penitipan, membebaskan si berutang, dan berlaku baginya sebagai pembayaran, asal penawaran itu telah dilakukan dengan cara menurut undangundang; sedangkan apa yang dititipkan secara itu tetap atas tanggungan si berpiutang.

Dalam hal seperti di atas, jika kreditur menolak pembayaran debitur, maka debitur dapat melakukan penawaran tunai apa yang diutangkannya dan jika kreditur menolaknya, maka debitur menitipkan uang atau barangnya kepada pengadilan, dalam praktek penyusunan permohonan konsinyasi, maka debitur menjadi penggugat dan kreditur menjadi tergugat. Grafika.hlm.1

67 H.S, Salim. 2005. Perkembangan Hukum Kontrak Innominaat di Imdonesia. Jakarta: Sinar

68 Sri Soedewi Masjchoen Sofwan, 1980, Hukum Perdata;Hukum Perutangan, UGM, Yogyakarta,hlm.97 
Dalam konsinyasi antara Supplier dan Pasar Swalayan pihak yang memiliki barang disebut konsinyor (consignor), sedangkan pihak yang mengusahakan penjualan barang disebut konsinyi (consignee).

Dalam konsinyasi terjalin hubungan yang erat antara Supplier, Pasar Swalayan dan konsumen. Hubungan antara Supplier dengan Pasar Swalayan adalah menyangkut penetapan harga jual beli atas produk yang diperdagangkan. Pemenuhan kualitas produk yang diperdagangkan sepenuhnya menjadi tanggung jawab Supplier. Pemenuhan kualitas jasa yang diperdagangkan sepenuhnya menjadi tanggung jawab Pasar Swalayan. Hubungan antara Pasar Swalayan dan konsumen terutama dilakukan dalam rangka memenuhi ketentuan-ketentuan hukum yang berkaitan dengan perlindungan konsumen dan transaksi jual beli.

Konsinyasi ini ada berdasarkan kesepakatan dari interaksi bisnis antara Supplier dengan Pasar Swalayan. Hubungan hukum dalam konsinyasi merupakan perjanjian campuran. Di dalamnya terkandung karakteristis perjanjian pemberian kuasa, perjanjian keagenan, perjanjian penitipan barang dan perjanjian jual beli.

Pemberian kuasa atau lastgeving yang diatur dalam Pasal 1792 KUHPer disebutkan sebagai suatu persetujuan dimana seorang A memberi kuasa kepada seorang B untuk melakukan sesuatu hal untuk kepentingan dan atas nama A. ${ }^{69}$

Apabila dihubungkan dengan konsinyasi, maka dalam pelaksanaan konsinyasi terkandung karakteristik perjanjian pemberian kuasa karena dalam konsinyasi Supplier memberikan kuasa kepada Pasar Swalayan untuk menjual barang yang telah diserahkan kepadanya meskipun hak milik atas barang itu masih berada di tangan Supplier. Disini kedudukan Supplier adalah sebagai pemberi kuasa dan Pasar Swalayan sebagai penerima kuasa.

Dikatakan terkandung karakteristik perjanjian keagenan karena Pasar Swalayan dalam konsinyasi berkedudukan sebagai pihak yang menjadi perantara mencarikan pembeli untuk kepentingan Supplier dengan mendapatkan komisi.

Dalam konsinyasi terdapat juga karakteristik perjanjian jual beli yaitu pada saat Pasar Swalayan melakukan transaksi jual beli dengan konsumen terhadap barang konsinyasi. Pasar Swalayan berkedudukan sebagai penjual ketika berhadapan dengan konsumen, meskipun barang yang dijualkannya itu merupakan milik dari Supplier.

Konsinyasi merupakan salah satu bentuk strategi produsen dalam pendistribusian produknya kepada konsumen. Secara garis besar, pendistribusian dapat diartikan sebagai

${ }^{69}$ Wirjono, Prodjodikoro, R. 2000,Asas-Asas Hukum Perjanjian, Cetakan VIII, Bandung : Mandar Maju,hlm.112 
kegiatan pemasaran yang berusaha memperlancar dan mempermudah penyampaian barang dan jasa dari produsen kepada konsumen, sehingga penggunaannya sesuai dengan yang diperlukan (jenis, jumlah, harga, tempat dan saat diperlukan) ${ }^{70}$.

Mekanisme dalam pelaksanaan konsinyasi yaitu produsen yang dalam hal ini diwakili oleh Supplier menitipkan produknya kepada pihak lain (Pasar Swalayan) untuk dijual kembali kepada konsumen dengan diikat dalam suatu perjanjian.Dalam proses ini Supplier dan pihak yang menjualkan produk (Pasar Swalayan) merupakan perantara produsen ke konsumen dalam aliran barang.

Konsinyasi selain memberikan keuntungan bagi kedua belah pihak, dimana bagi Supplier penitipan barang dapat dijadikan sarana mempromosikan produk-produknya, terutama untuk produk-produk baru, sedangkan bagi Pasar Swalayan cara seperti ini mengurangi risiko kerugian karena apabila barang yang dititipkan itu tidak habis terjual, maka dapat dikembalikan kepada Supplier. Namun banyak juga permasalahan yang muncul dalam perjanjian konsinyasi tesebut. Kompleksnya permasalahan dalam perjanjian konsinyasi yang tidak ada pengaturan khusus dalam KUHPerdata memerlukan perlindungan hukum dan penyelesaian secara yuridis untuk menjamin keadilan antara pihak distributor dengan pihak pedagang (agen). Konsinyasi, sebagai bentuk perjanjian tidak bernama belum diatur secara khusus dalam suatu peraturan perundang-undangan. Pengaturan ini penting untuk memberikan perlindungan hukum kepada semua pihak, baik kepada Supplier, Pasar Swalayan juga konsumen sebagai pengguna

\section{B. Permasalahan}

Permasalahan yang penulis teliti adalah bagaimanakah pengaturan perjanjian konsinyasi terhadap Pasal 1338 KUHPerdata?

\section{Pembahasan}

Sejauh ini tidak terdapat suatu pengaturan khusus mengenai perjanjian konsinyasi di Indonesia. hubungan antara para pihak dalam perjanjian konsinyasi dan para prinsipalnya yang timbul di dalam parktik di Indonesia hanya didasarkan kepada kesepakatan para pihak.. Walaupun sepakat merupakan unsur utama dalam syarat sahnya perjanjian yakni terpenuhinya asas konsensuil. ${ }^{71}$ Yang mana para pihak yang bertransaksi bersepakat, setuju dan apa yang

${ }^{70}$ Kotler, Philip dkk. 2000. Manajemen Pemasaran Perspektif Asia. Buku kedua. Edisi pertama. Andi. Yogyakarta.hlm.112

${ }^{71}$ Subekti. R, 1984, Aneka Perjanjian,:Alumni, Bandung,hlm.26 
dikehendaki oleh pihak lain sehingga terjadi pertemuan kehendak, namun pengaturan yang lebih khusus dan spesifik lebih dibutuhkan untuk mendukung terciptanya transaksi yang sinergis dan memiliki dasar hukum yang jelas dan spesifik.

Pengaturan perjanjian konsinyasi sampai saat ini bernaung pada buku III KHPerdata mengenai Perikatan. Di dalam buku III diatur mengenai asas kebebasan berkontrak yang pada hekekatnya mengatur bahwa setiap perjanjian bebas untuk dibuat oleh para pihak selama perjanjian itu memenuhi syarat sahnya perjanjian.

Pasal 1338 ayat (1) KUHPerdata menentukan bahwa semua perjanjian yang dibuat secara sah berlaku sebagai undang-undang bagi mereka yang membuatnya. Pasal ini mengandung asas hukum kebabsan berkontrak yang dalam bahasa inggris disebut "freedom of contract" dan dalam bahasa Belanda disebut "partij otonomi”. Pasal ini juga mengandung asas "pacta sunt servanda" yang artinya bahwa perjanjian menjadi hukum atau undangundang bagi para pihak yang membuatnya, atau dengan kata lain perjanjian itu mengikat dan menimbulkan sanksi jika ada pihak yang melanggar.

Pada awalnya perjanjian konsinyasi ini tidak dikenal dalam pranata hukum perjanjian Indonesia namun karena asas kebebasan berkontrak yang dianut oleh hukum perjanjian Indonesia maka apapun bentuk atau konstruksi perjanjian yang akan dibuat di dalam yurisdiksi hukum Indonesia akan mempunyai kekuatan hukum dan dilindungi oleh hukum perjanjian Indonesia selama tidak bertentangan dengan peraturan perundang-undangan yang berlaku, norma-norma kepatutan yang hidup dan berkembang di masyarakat serta tidak bertentangan dengan kepentingan umum. Mengenai hal ini dapat dilihat dalam Pasal 1338 KUHPerdata yang menyebutkan:"Semua perjanjian yang dibuat secara sah berlaku sebagai undang-undang bagi mereka yang membuatnya. Suatu perjanjian tidak dapat ditarik kembali selain dengan sepakat kedua belah pihak atau karena alasan yang oleh undang-undang dinyatakan cukup untuk itu. Suatu perjanjian harus dilaksanakan dengan iktikad baik.”

Asas kebebasan berkontrak yang dianut oleh BW (Pasal 1338 ayat 1) memungkinkan perkembangan dalam hukum perjanjian jarena masyarakat menurut kebutuhannya dapat menciptakan sendiri bermacam-macam perjanjian di samping "perjanjian-perjanjian khusus" yang diatur dalam BW, asal perjanjian itu tidak bertentangan dengan undanng-undang, ketertuban umum atau kesusilaan (mempunyai causa yang "halal" menurut Pasal 1320 KUHPerdata.

Dari ketentuan yang terdapat pada pasal 1338 KHPerdata di atas maka dapat disimpulkan perjanjian konsinyasi didasari oleh ketentuan hukum Pasal 1338 ayat (1) KUHPerdata mengenai kebebasan berkontrak. Ketika para pihak yang mengadakan suatu 
perjanjian konsinyasi sepakat untuk melaksanakan perjanjian dengan klausul perjanjian konsinyasi maka perjanjian ini adalah sah dan mengikat sebagai undang-undang bagi pihak yang mengadakan perjanjian.

Perjanjian konsinyasi ini dapat dikategorikan sebagai perjanjian tidak bernama (Onbenoemde) yaitu perjanjian-perjanjian yang tidak diatur namun terdapat dalam masyarakat. Lahirnya perjanjian ini di dalam praktik adalah berdasarkan asas kebebasan berkontrak atau partij otonomi. Asas kebebasan berkontral pada Pasal 1338 KUHPerdata yang menjadi dasar dibentuknya perjanjian konsinyasi inilah yang mengakibatkan perjanjian konsinyasi dapat dikategorikan sebagai perjanjian tidak bernama.

Sesuai dengan apa yang diatur pada Pasal 1233 KUHPerdata maka perjanjian konsinyasi antara para pihak merupakan perikatan yang lahir dari perjanjian. Perikatan yang lahir karena adanya kesepakatan antara para pihak kemudian para pihak setuju untuk saling mengikatkan diri dalam suatu perjanjian.

Pasal 1313 KUHPerdata menyebutkan bahwa suatu perjanjian atau persetujuan dengan mana satu orang atau lebih mengikatkan dirinya terhadap satu orang lain atau lebih. Maka dapat dilihat bahwa para principal sebagai pihak pertama mengikatkan dirinya terhadap suplier. Dasar bagi mereka untuk saling mengkatkan diri dituangkan dalam perjanjian konsinyasi baik mengenai hak maupun kewajiban masing-masing pihak.

Sesuai dengan Pasal 1319 KUHPerdata yang menyebutkan bahwa semua perjanjian, baik yang mempunyai suatu nama khusus, maupun yang tidak dikenal dengan suatu nama tertentu, tunduk pada peraturan-peraturan umum yang telah disebut di atas. Bila melihat perjanjian konsinyasi tersebut, maka konstruksi perjanjian seperti ini sebelumnya tidak dikenal pada buku III KUHPerdata, namun dengan adanya Pasal 1319 maka dimungkinkan bahwa Hukum Perjanjian memberi kekuatan hukum terhadap perjanjian konsinyasi selama tidak bertentangan dengan peraturan-peraturan umum, yang termuat di dalam buku UU tentang benda beserta buku III tentang perikatan pada KUHPerdata. Pasal 1319 KUHPerdata menunjukkan bahwa buku III KUHPerdata menganut asas terbuka. Maksudnya adalah dimungkinkan dibuatnya perikatan-perikatan selain yang diatur dalam Buku tentang perikatan (Buku III) selama perjanjian yang dibuat tersebut tidak bertentangan peraturan umum yang terdapat pada Buku II dan Buku III.

Perjanjian konsinyasi yang dikategorikan perjanjian tidak bernama ini juga telah memenuhi unsur-unsur syarat sahnya suatu perjanjian berdasarkan Pasal 1320 KHUPerdata, antara lain: 
1. Sepakat mereka yang mengikatkan dirinya

Dengan sepakat atau perizinan, dimaksudkan bahwa kedua subjek yang mengadakan perjanjian itu harus bersepakat, setuju atau seia-sekata mengenai hal-hal pokok dari perjanjian yang diadakan itu. ${ }^{72}$

2. Cakap untuk membuat suatu perjanjian

Orang yang membuat suatu perjanjian harus cakap menurut hukum. Pada asasnya, setiap orang yang sudah dewasa atau akil baliq dan sehat pikirannya adalah cakap menurut hukum. Kecakapan para pihak dalam perjanjian konsinyasi ditentukan oleh kemampuan subjek hukum dalam mengemban hak dan kewajiban hukum bagi perorangan.

3. Suatu hal tertentu

Syarat yang ketiga mengenai hal tertentu jika dianalisis maka objek perjanjian konsinyasi adalah harus jelas.

4. Suatu sebab yang halal.

Hal yang harus diperhatikan dalam hal "kausa yang halal" adalah isi perjanjian yang menggambarkan tujuan yang dicapai oleh para pihak. Kausa yang halal dapat diteliti dari tujuan dibuatnya perjanjian konsinyasi ini. Tujuan tersebut dapat diidentifikasi dari latar belakang dibuatnya perjanjian konsinyasi yaitu adanya kebutuhan akan kepastian oleh principal yang mengadakan transasksi atas pemenuhan objek perjanjian. Tujuan atau kausa dari perjanjian konsinyasi tersebut adalah sah dan halal karena tidak bertentangan dengan undang-undang, kesusilaan dan ketertban umum.

Dari penjabaran tentang syarat-syarat sahnya perjanjian di atas maka perjanjian konsinyasi memnuhi unsure-unsur untuk sahnya suatu perjanjian yang diatur pada Pasal 1320 KUHPerdata.

\section{Penutup}

\section{Kesimpulan}

Pengaturan perjanjian konsinyasi sampai saat ini bernaung pada buku III KHPerdata mengenai Perikatan. Di dalam buku III diatur mengenai asas kebebasan berkontrak yang pada hekekatnya mengatur bahwa setiap perjanjian bebas untuk dibuat oleh para pihak selama perjanjian itu memenuhi syarat sahnya perjanjian.

Pasal 1338 ayat (1) KUHPerdata menentukan bahwa semua perjanjian yang dibuat secara sah berlaku sebagai undang-undang bagi mereka yang membuatnya. Pasal ini

\footnotetext{
${ }^{72}$ Ibid, hlm. 117
} 
mengandung asas hukum kebabsan berkontrak yang dalam bahasa inggris disebut "freedom of contract" dan dalam bahasa Belanda disebut "partij otonomi”. Pasal ini juga mengandung asas "pacta sunt servanda" yang artinya bahwa perjanjian menjadi hukum atau undangundang bagi para pihak yang membuatnya, atau dengan kata lain perjanjian itu mengikat dan menimbulkan sanksi jika ada pihak yang melanggar.

\section{Saran}

a. Harus membuat aturan yang khusus yang berhubungan dengan perjanjian tidak bernama khususnya perjanjian konsinyasi.

b. Harus ada pengawasan yang dilakukan oleh pemerintah yang berhubungan dengan perjanjian konsinyasi tersebut.

\section{DAFTAR PUSTAKA}

\section{Buku}

H.S, Salim. 2005. Perkembangan Hukum Kontrak Innominaat di Imdonesia. Jakarta: Sinar Grafika.

Philip Kotler, dkk. 2000. Manajemen Pemasaran Perspektif Asia. Buku kedua. Edisi pertama. Andi. Yogyakarta.

Sri Soedewi Masjchoen Sofwan, 1980, Hukum Perdata;Hukum Perutangan, UGM, Yogyakarta,

Subekti. R, 1984, Aneka Perjanjian,:Alumni, Bandung

Wirjono, Prodjodikoro, R. 2000,Asas-Asas Hukum Perjanjian, Cetakan VIII, Bandung : Mandar Maju

\section{Perundangan}

Kitab Undang-Undang Hukum Perdata

Kitab Undang-Undang Hukum Dagang

UU.No.8 Tahun 1999 Tentang Hukum Perlindungan Konsumen 